\title{
Article
}

\section{A dynamic portal for a community-driven, continuously updated classification of Fungi and fungus-like organisms: outlineoffungi.org}

Wijayawardene $\mathrm{NN}^{1}$, Hyde $\mathrm{KD}^{2}$, Dai $\mathrm{DQ}^{1, *}$, Tang $\mathrm{LZ}^{1, *}$, Aptroot $\mathrm{A}^{3}$, CastañedaRuiz $\mathrm{RF}^{4}$, Druzhinina $\mathrm{IS}^{5}$, Cai $\mathrm{F}^{5}$, Ekanayaka $\mathrm{AH}^{2}$, Erdoğdu $\mathrm{M}^{6}$, Fiuza $\mathrm{PO}^{7}$, Gentekaki $E^{2}$, Goto $B^{8}$, Haelewaters $D^{9,10,11,12}$, Hongsanan $S^{13}$, Jeewon $R^{14}$, Kirk $\mathbf{P M}^{15}$, Jayalal $\mathrm{RGU}^{16}$, Karunarathna $\mathrm{SC}^{17,18,19}$, Wanasinghe $\mathrm{DN}^{17,18,19}$, Lumbsch HT $^{20}$, Madrid $\mathbf{H}^{21,22}$, Maharachchikumbura $\mathrm{SSN}^{23}$, Monteiro $\mathrm{JS}^{24}$, Shivaprakash $\mathbf{N}^{25}$, Pfliegler $\mathbf{W P}^{26}$, Phillips AJL ${ }^{27}$, Saxena $\mathbf{R K}^{28}$, Stadler $\mathbf{M}^{29,30}$, Tian $\mathbf{Q}^{2}$, Tokarev $\mathbf{Y S}^{31}$, Tsurykau $A^{32,33}$, Ertz $D^{34,35}$, Lee $\mathbf{H B}^{36}$, Etayo $\mathrm{J}^{37}$, Vizzini $\mathrm{A}^{38}$, Jones $\mathrm{EBG}^{39}$, Lin $\mathrm{CG}^{2}$, Li $\mathrm{WJ}^{2}$, Dai $\mathrm{YC}^{40}$, Fan $\mathrm{XL}^{41}$, McKenzie EHC ${ }^{42}$, Shivas RG $^{43}$, Hustad $V^{44}$, Leontyev DV $^{45}$, de Hoog GS $^{46}$, Niskanen $T^{47}$, Boekhout $\mathbf{T}^{48,49}$, Gaya $\mathbf{E}^{50}$, Thines $\mathbf{M}^{51,52}$

${ }^{1}$ Center for Yunnan Plateau Biological Resources Protection and Utilization, College of Biological Resource and Food Engineering, Qujing Normal University, Qujing, Yunnan 655011, P.R. China.

${ }^{2}$ Center of Excellence in Fungal Research, Mae Fah Luang University, Chiang Rai 57100, Thailand

${ }^{3}$ Laboratório de Botânica / Liquenologia, Instituto de Biociências, Universidade Federal de Mato Grosso do Sul, Avenida Costa e Silva s/n, Bairro Universitário, CEP 79070-900, Campo Grande, Mato Grosso do Sul, Brazil

${ }^{4}$ Instituto de Investigaciones Fundamentales en AgriculturaTropical, 'Alejandro de Humboldt' (INIFAT), Santiago deLas Vegas, Habana, Cuba

${ }^{5}$ Fungal Genomics Group, College of Resources and Environmental Sciences, Nanjing Agricultural University, Nanjing, Jiangsu, P.R. China.

${ }^{6}$ Department of Landscape Architects, Faculty of Agriculture, Kırşehir Ahi Evran University, Kırşehir, Turkey

${ }^{7}$ Universidade Federal do Rio Grande do Norte (UFRN), Programa de Pós-graduação em Sistemática e Evolução, Centro de Biociências, Campus Universitário, Av. Senador Salgado Filho, 3000, Lagoa Nova, 59078-970, Natal-RN, Brazil

${ }^{8}$ Departamento de Botânica e Zoologia, Universidade Federal do Rio Grande do Norte, Campus Universitário, 59072-970, Natal, RN, Brazil

${ }^{9}$ Faculty of Science, University of South Bohemia, Branišovská 31, 37005 České Budějovice, Czech Republic

${ }^{10}$ Department of Botany and Plant Pathology, Purdue University, 915 W. State Street, West Lafayette, Indiana 47907, USA

${ }^{11}$ Herbario UCH, Universidad Autónoma de Chiriquí, Apartado Postal 0427, David, Panama

12 Department of Biology, Research Group Mycology, Ghent University, K.L. Ledeganckstraat 35, 9000 Ghent, Belgium

${ }^{13}$ Shenzhen Key Laboratory of Laser Engineering, College of Optoelectronic Engineering, Shenzhen University, Shenzhen, P.R. China

${ }^{14}$ Department of Health Sciences, Faculty of Science, University of Mauritius, Reduit, Mauritius

${ }^{15}$ Biodiversity Informatics and Spatial Analysis, Royal Botanic Gardens, Kew, Richmond, Surrey TW9 3DS, UK

${ }^{16}$ Department of Natural Resources, Sabaragamuwa University of Sri Lanka, Belihuloya, 70140, Sri Lanka

${ }^{17}$ CAS key Laboratory for Plant Diversity and Biogeography of East Asia, Kunming Institute of Botany, Chinese Academy of Science, Kunming 650201, Yunnan, P.R. China

${ }^{18}$ World Agroforestry Centre, East and Central Asia, Kunming 650201, Yunnan, P.R. China

${ }^{19}$ Centre for Mountain Futures (CMF), Kunming Institute of Botany, Kunming, Yunnan, 650201, P.R. China

${ }^{20}$ Science \& Education, The Field Museum, 1400 S. Lake Shore Drive, Chicago, IL 60605, USA

${ }^{21}$ Escuela de Tecnología Médica, Facultad de Salud, Universidad Santo Tomás, Los Carreras 753, Osorno, Chile

${ }^{22}$ Centro de Genómica y Bioinformática, Facultad de Ciencias, Universidad Mayor, Camino La Pirámide 5750, Huechuraba, Santiago, Chile 
${ }^{23}$ School of Life Science and Technology, University of Electronic Science and Technology of China, Chengdu 611731, P.R. China

${ }^{24}$ Coordenação de Botânica, Museu Paraense Emílio Goeldi, Avenida Perimetral, 1901, Terra Firme, 66077-530, Belém, Pará, Brazil

${ }^{25}$ ICAR-Central Plantation Crops Research Institute (ICAR-CPCRI), Regional Station, Vittal - 574243, Karnataka, India

${ }^{26}$ Department of Molecular Biotechnology and Microbiology, University of Debrecen, Debrecen, Egyetem tér 1., 4032, Hungary

${ }^{27}$ Universidade de Lisboa, Faculdade de Ciências, Biosystems and Integrative Sciences Institute (BioISI), Campo Grande, 1749-016 Lisbon, Portugal

${ }^{28}$ Birbal Sahni Institute of Palaeosciences, 53 University Road, Lucknow-226007, India

${ }^{29}$ Department of Microbial Drugs, Helmholtz-Zentrum für Infektionsforschung GmbH, Inhoffenstrasse 7, 38124, Braunschweig, Germany

${ }^{30}$ German Centre for Infection Research (DZIF), partner site Hannover-Braunschweig, 38124 Braunschweig, Germany

${ }^{31}$ Laboratory of Microbiological Control, All-Russian Institute of Plant Protection, Shosse Podbelskogo 3, Pushkin, St. Petersburg, 196608, Russia

${ }^{32}$ F. Skorina Gomel State University, Department of Biology, Sovetskaja Str. 104, Gomel 246019, Belarus

${ }^{33}$ Samara National Research University, Institute of Natural Sciences, Department of Ecology, Botany and Nature, Protection, Moskovskoye shosse 34, Samara 443086, Russia

${ }^{34}$ Meise Botanic Garden, Department of Research, Nieuwelaan 38, BE-1860 Meise, Belgium

${ }^{35}$ Fédération Wallonie-Bruxelles, Direction générale de l'Enseignement non obligatoire et de la Recherche scientifique, Rue A. Lavallée 1, BE-1080 Bruxelles, Belgium

${ }^{36}$ Environmental Microbiology Laboratory, Department of Agricultural Biological Chemistry, College of Agriculture \& Life Sciences, Chonnam National University, Gwangju 61186, Korea

${ }^{37}$ Institute Zizur Mayor, Ronda San Cristóbal 196, 31180 Zizur Mayor, Navarra, Spain

${ }^{38}$ Department of Life Sciences and Systems Biology, University of Torino, Viale PA Mattioli 25, 10125 Torino, Italy

${ }^{39}$ Nantgaredig, 33 B St. Edwards Road Southsea Hants, Hampshire PO5 3DH, UK

${ }^{40}$ Institute of Microbiology, Beijing Forestry University, East Qinghua Road, 35, Haidian, Beijing 100083, P.R. China

${ }^{41}$ The Key Laboratory for Silviculture and Conservation of Ministry of Education, Beijing Forestry University, Beijing 100083, P.R. China

${ }^{42}$ Manaaki Whenua-Landcare Research, Private Bag No 92170, Auckland, New Zealand

${ }^{43}$ Centre for Crop Health, University of Southern Queensland, Toowoomba 4350, Australia

${ }^{44}$ Department of Natural Sciences, Northwest Missouri State University, Maryville, Missouri, 64468, USA

${ }^{45}$ Department of Botany, H.S. Skovoroda Kharkiv National Pedagogical University, Valentynivs'ka 2, Kharkiv 61168, Ukraine

${ }^{46}$ Center of Expertise in Mycology of Radboud University Medical Center / Canisius Wilhelmina Hospital, Nijmegen, The Netherlands

${ }^{47}$ The Jodrell Laboratory Royal Botanic Gardens, Kew, Surrey TW9 3AB, UK

${ }^{48}$ Westerdijk Fungal Biodiversity Institute, Utrecht, The Netherlands

${ }^{49}$ Institute of Biodiversity and Ecosystem Dynamics (IBED), University of Amsterdam, Amsterdam, the Netherlands

${ }^{50}$ Comparative Plant and Fungal Biology, Royal Botanic Gardens, Kew, TW9 3AE, UK

${ }^{51}$ Goethe University, Department for Biological Sciences, Institute of Ecology, Evolution and Diversity, Max-vonLaueStr. 13, D-60486 Frankfurt am Main, Germany

${ }^{52}$ Senckenberg Biodiversity and Climate Research Centre, Senckenberganlage 25, D-60325 Frankfurt am Main, Germany

Wijayawardene NN, Hyde KD, Dai DQ, Tang LZ, Aptroot A, Castañeda-Ruiz RF, Druzhinina IS, Cai F, Ekanayaka AH, Erdoğdu M, Fiuza PO, Gentekaki E, Goto BT, Haelewaters D, Hongsanan S, Jeewon R, Kirk PM, Jayalal U, Karunarathna SC, Wanasinghe DN, Lumbsch HT, Madrid H, Maharachchikumbura SSN, Monteiro JS, Shivaprakash N, Pfliegler WP, Phillips AJL, Saxena RK, Stadler M, Tian Q, Tokarev YS, Tsurykau A, Ertz D, Lee HB, Etayo J, Vizzini A, Jones EGB, Lin CG, Li WJ, Dai YC, Fan XL, McKenzie EHC, Shivas RG, Hustad V, Leontyev DV, de Hoog GS, Niskanen T, Boekhout T, Gaya E, Thines M 2020 - A dynamic portal for a community-driven, continuously updated classification of Fungi and fungus-like organisms: outlineoffungi.org. Mycosphere 11(1), 1514-1526, Doi 10.5943/mycosphere/11/1/11

\section{Abstract}

The website http://outlineoffungi.org, is launched to provide a continuous up-to-date classification of the kingdom Fungi (including fossil fungi) and fungus-like taxa. This is based on 
recent publications and on the outline of fungi and fungus-like taxa published recently (Mycosphere 11, 1060-1456, doi 10.5943/mycosphere/11/1/8). The website is continuously updated according to latest classification schemes, and will present an important platform for researchers, industries, government officials and other users. Users can provide input about missing genera, new genera, and new data. They will also have the opportunity to express their opinions on classifications with notes published in the 'Notes' section of the webpage following review and editing by the curators and independent experts. The website will provide a system to stay abreast of the continuous changes in fungal classification and provide a general consensus on the systematics of fungi.

Keywords - classification - community-driven - higher ranks - outline - portal - taxa

\section{Introduction}

Classification of fungi is a topic of key concern among mycologists and other researchers, such as plant pathologists and those in the applied sciences. Accurate species identification and classification are prerequisites for precise scientific communication and for future comparative studies. Morphology-based classification was widely used before DNA sequence data became available and opened up a more objective tool to infer natural relationships (White et al. 1990). In traditional taxonomy, asexual fungi have been placed in the Subdivision Deuteromycotina (Ainsworth 1966), which comprised three classes, Coelomycetes, Hyphomycetes and Agonomycetes (mycelia sterilia) (Sutton 1980). None of these taxa are used anymore, but the designations, coelomycetes and hyphomycetes, are still frequently used in an informal, descriptive manner. Kendrick (1989) stressed the importance of incorporating asexual fungi and sexual fungi into one classification system and Taylor (1995) discussed the possibility of using one classification system with the application of DNA sequences and phylogeny. In recent years, multi-locus phylogenetic analyses have come at the forefront of modern fungal taxonomy (e.g. Jiang et al. 2020, Samarakoon et al. 2020, Wibberg et al. 2020). Furthermore, DNA sequence analyses are used to link asexual morphs with sexual morphs. As a result of these developments, dual nomenclature that existed for asexual and sexual morphs was discontinued (Hawksworth et al. 2011), and a base for a global classification scheme for fungi developed.

\section{Previous outlines of fungi and their limitations}

Classification of sexual fungi has been presented as an outline by Eriksson (1982, 1999, 2001, 2005), Eriksson \& Hawksworth (1986, 1998a, b), and Lumbsch \& Huhndorf (2007, 2010). Hyde et al. (2011) published the first outline of asexual genera with links to their sexual genera, and this was updated by Wijayawardene et al. (2017b). Wijayawardene et al. (2018) incorporated both asexual and sexual genera in the most recent Outline of the Ascomycota. Wijayawardene et al. (2017a, b, 2018, 2020) and He et al. (2019) provided notes for all fungal (including fossil fungi) and fungus-like genera. Most recently, Wijayawardene et al. (2020) provided a classification of all fungi and fungus-like taxa as an outline that was authored by over 150 mycologists. These authors recognized two crucial limitations while compiling the outline.

1. As classification is not an exact science, there can be disagreement and dispute among different research groups on taxonomic boundaries of genera and higher taxa.

2. As phylogenetic data are still being collected at a very high pace and increasingly being used in taxonomy, there is the necessity of constantly updating classification schemes and incorporate new findings.

\section{Overcoming limitations of static publication}

Disagreements on the classification and identification of fungi can occur as a result of different types of DNA analyses performed, different gene regions analysed, the impact of taxonomic sampling, the significance of specific morphs used in species delineation, and the inclusion of type species and type specimens in analyses. Therefore, Wijayawardene et al. (2020) 
included some alternative views on higher-level classification. It is important for readers to evaluate different classification proposals and make decisions as to which ones they will follow based on the available data and expert opinion. Collection of updated data was also a huge challenge while compiling the outline of Wijayawardene et al. (2020) as fungi and fungus-like organisms are extremely diverse and their classification and taxonomy is in a constant state of flux. As a consequence, a 'cut-off' date for gathering published data was set by Wijayawardene et al. (2020), as the authors were well-aware that continuous updating of the classification scheme would be necessary. As a result, the importance of a flexible, online platform has been discussed as a means to overcome static classification proposals.

\section{Other online databases}

Online databases are used as tools in current studies in mycology, including taxonomy, nomenclature and classification (Prakash et al. 2017, Větrovský et al. 2020). For example, Index Fungorum (http://www.indexfungorum.org), MycoBank (https://www.mycobank.org) and FungalNames (http://www.fungalinfo.net/) are important web tools that mainly deal with nomenclature. Several other important web based databases such as onestopshopfungi.org (https://onestopshopfungi.org/), dothideomycetes.org (https://dothideomycetes.org/), fungalgenera.org (https://fungalgenera.org/), facesoffungi.org (http://www.facesoffungi.org/), theyeasts.org (https://theyeasts.org/) provide information on pathogenic genera, Dothideomycetes genera, typification data, descriptions of species and other taxonomic ranks, and yeast genera, respectively (Jayasiri et al. 2015, Jayawardena et al. 2019, Monkai et al. 2019, Pem et al. 2019). Doctor Fungus (http://www.mycosesstudygroup.org/), Mycology Online (http://www.mycology.adelaide.edu.au/), and the Aspergillus and Aspergillosis Website (http://www.aspergillus.org.uk/) are dedicated websites for clinically important fungi. The website http://www.marinefungi.org deals with the latest taxonomy of marine fungi (Jones et al. 2019). None of these databases provides general changes in consensus classification and the reasons for changes. Hence, it is essential to have a database, which, based on new studies, is being continuously updated with balanced changes of a community-supported consensus classification.

\section{Outline of Fungi web page}

The Outline of Fungi web site is established to address the limitations recognized during the compilation of the published Outline of Fungi (Wijayawardene et al. 2020). The main objectives of the online resource, 'outlineoffungi.org' are to:

1. Present a continually updated consensus classification of fungi and fungus-like organisms based on recent literature and expert opinion.

2. Provide notes for important changes and additions to the outline.

3. Provide an opportunity for researchers to add missing data, suggestions to modify data, and provide critical comments on the consensus outline, based on their expert opinion.

\section{Fossil fungi}

Fossil fungi are the ancestors of current fungi and represent extinct lineages, some of which evolved relatively early, probably more than 1500 million years ago. They were buried in sediments, silicified or trapped in amber, and have been preserved until now in sedimentary rocks (Samarakoon et al. 2020). They generally tend to be microscopic. However, a few large fungal bodies, such as mushrooms, have also been found as fossils. Fossil fungal remnants are found in the form of spores, mycelia, sporophores, symbiotic associations, and are commonly observed in macerated residues prepared for palynological studies. Although fungal remains are encountered in sediments of all ages, their frequency increases remarkably in the Tertiary Period (Dilcher 1965, Pirozynski \& Weresub 1979, Kalgutkar \& Jansonius 2000, Saxena \& Tripathi 2011). Because of the fragmentary remains that make up the vast majority of fungal remains, fossil fungi usually lack characteristic features that are diagnostic, hampering their classification with extant fungi. Since DNA survival is limited, they are described on the basis of morphological characters only. For 
example, spore taxa are characterised on their shape, size, symmetry, number and nature of apertures, septa and spore wall characters, which often allow up to genus-level classifications. In addition, fossil sporocarps without spores or hyphal details can mostly be assigned to order level or above. All fossil fungal taxa are registered with a recognized nomenclatural repository, e.g. Index Fungorum/MycoBank, to make their references accessible world-wide. This also helps ensuring that they are validly published, avoiding unnecessary introductions of later homonyms.

\section{Fungus-like taxa}

Fungal-like characteristics have evolved multiple times, both in prokaryotes (e.g. Myxobacteria) and eukaryotes (e.g. slime molds, Labyrinthulomycota, Oomycota). Myxobacteria are, however, almost exclusively studied by bacteriologists, and many members of Labyrinthulomycota have been described under the zoological code in the corresponding phylum Labyrinthulida. In more recent classifications of myxomycetes, which have long been described under the International Code of Nomenclature for algae, fungi and plants (ICNafp), a classification entirely based on the International Code of Zoological Nomenclature (ICZN) is adopted (Adl et al. 2005). However, but this approach was criticized by Ronikier \& Halamski (2018), who emphasized that the transfer of myxomycetes to zoological nomenclature would destabilize the nomenclature of the group, due to the existence of numerous homonyms. For this reason, the most recent published classification of Eumycetozoa was based on the botanical nomenclature (Leontyev et al. 2019). However, most of the non-Eumycetozoan slime molds, such as protosteloids, acrasids, copromyxids, fonticulids, or guttulinopsids, were described by protozoologists using zoological nomenclature. These groups, therefore, should be covered by ICZN. However, the Preamble 8 of the ICNafp states that the 'slime molds' are considered among the organisms for which the Code is applied, while ICZN does not mention these organisms at all, so coordination between ICZN and ICNafp is needed to resolve this issue.

The group most closely resembling opisthokont fungi are Oomycota, because of their hyphal growth, osmotrophic nutrition and formation of large numbers of asexual spores (Dick 2001, Beakes \& Thines 2017). Because of these similarities, they have always been described under the ICNafp and its predecessors. Their early-diverging lineages mostly form only small, holocarpic thalli, i.e. the entire thallus converts into a sporangium. This is similar to the trophocytes found in some other members of the Straminipila-Alveolata-Rhizaria supergroup (Burki et al. 2007) groups, such as Perkinsozoa. However, the monophyletic branch starting from Miraculaceae (Buaya et al. 2017) until the highly diversified downy mildews (Thines \& Choi 2016) is commonly recognised as the phylum Oomycota (Beakes \& Thines 2017), and thus, treated under the ICNafp. Within Oomycota, the higher-level classification is still not fully resolved, owing to the difficulties in obtaining multiple genes for in-depth phylogenetic analyses from the often obligate biotrophic and holocarpic lineages that diverge before the main split into Saprolegniomycetes and Peronosporomycetes (Beakes \& Thines 2017). Another poorly-known group related to Oomycota, Hyphochytriomycota, is usually treated under the ICNafp as well, but only few species of this group have been discovered and their higher-level relationships, as well as their relationships to some bacteriovorous protists and oomycetes are still poorly resolved. Thus, it is expected that for both oomycetes and hyphochytrids, there will be considerable efforts necessary to stabilise their nomenclature, which will also be reflected in the Outline of Fungi website.

\section{Construction}

As a starting point, all fungal genera in the database are listed according to Wijayawardene et al. (2020). The database will be updated based on new studies and observations by the users.

\section{Database interface and visualization}

The homepage comprises nine tabs. Viewers can follow them and use the underlying functions with a simple and user-friendly interface (Fig. 1). 


\section{Tools included in homepage}

1. Home: The homepage provides an overview of the kingdom Fungi. Objectives of launching the website are also provided. (Fig. 1)

2. Outline: The 'Outline' provides a recent consensus taxonomic classification of the kingdom Fungi and fungus-like taxa of other kingdoms (e.g., slime moulds, oomycetes). (Fig. 2)

3. Archives: The 'Archives' provides recently published outlines.

4. Sexual-asexual links: This will be updated with all pleomorphic genera.

5. Curators: This section provides a list and contact details of the curators of the website (see Table 1).

6. History: This section provides a brief history of the classification of kingdom Fungi and fungus-like taxa.

7. References: This section provides reference list of citations used in the entries, history and related information.

8. Notes: The 'Notes' section publishes recent changes in outline since Wijayawardene et al. 2020 (see below for further details).

9. Contact: The 'Contact' section provides contact details for the website and allows users to address any comments and suggestions.

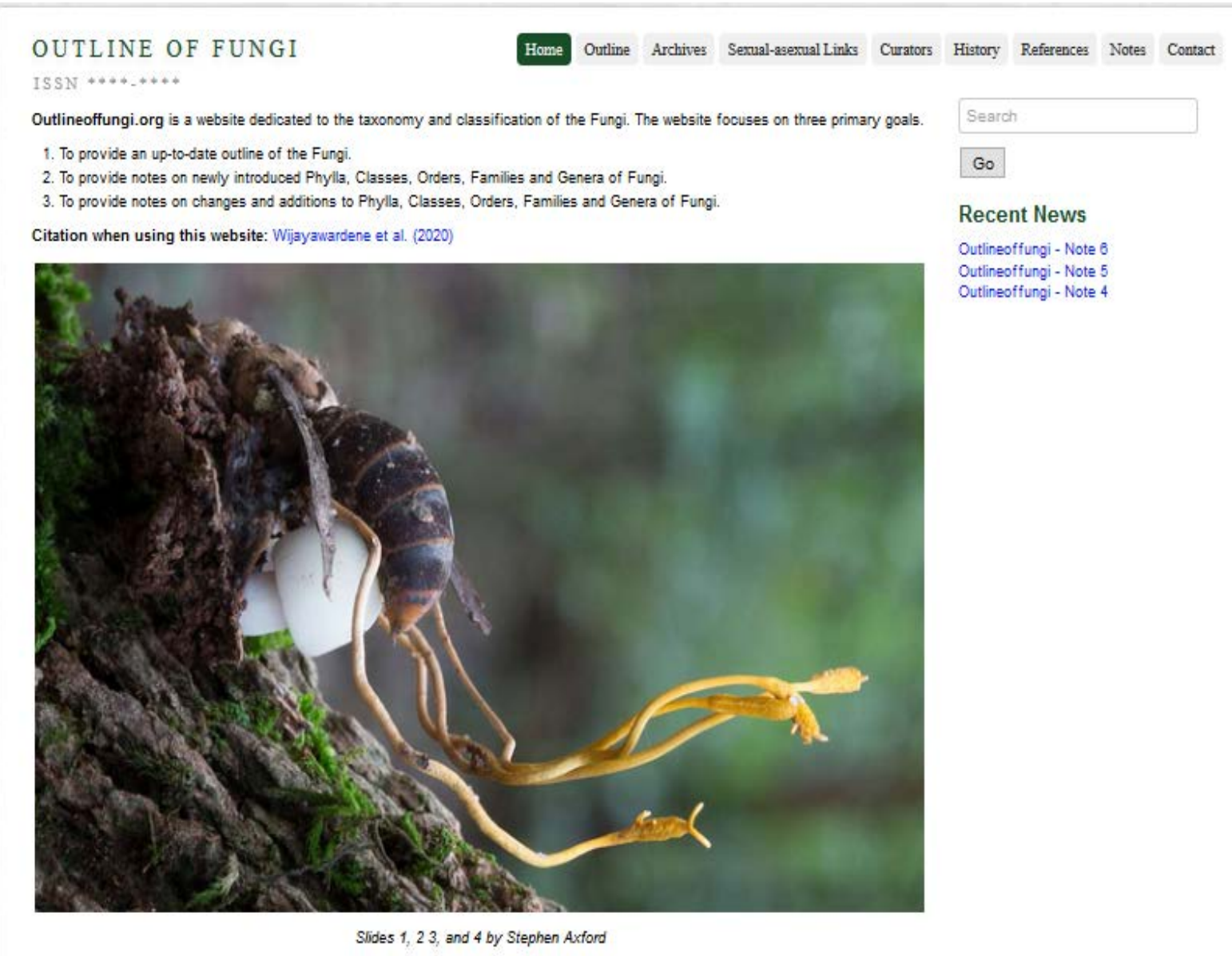

Figure 1 - The homepage view of outlineoffungi.org 


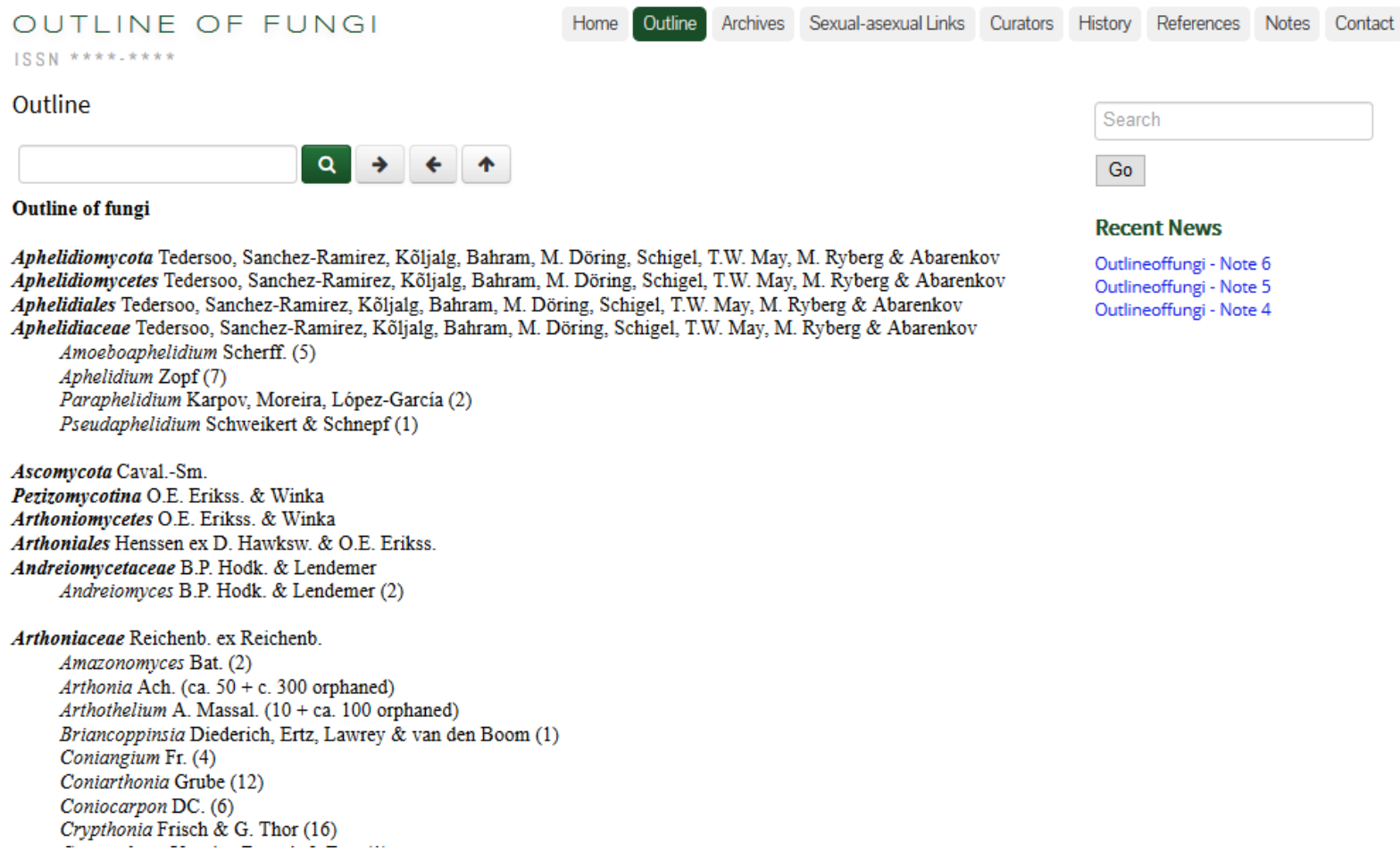

Outline

\section{$Q \rightarrow \leftarrow \uparrow$}

Outline of fungi

Aphelidiomycota Tedersoo, Sanchez-Ramirez Kõljalg. Bahram, M. Döring Schigel TW May, M Ryberg \& Abarenkov Aphelidiomycetes Tedersoo, Sanchez-Ramirez, Kõljalg, Bahram, M. Döring, Schigel, T.W. May, M. Ryberg \& Abarenkov Aphelidiales Tedersoo, Sanchez-Ramirez, Kõljalg, Bahram, M. Döring, Schigel, T.W. May, M. Ryberg \& Abarenkov Aphelidiaceae Tedersoo, Sanchez-Ramirez, Kõljalg, Bahram, M. Döring, Schigel, T.W. May, M. Ryberg \& Abarenkov Amoeboaphelidium Scherff (5)

Aphelidium Zopf (7)

Paraphelidium Karpov, Moreira, López-García (2)

Pseudaphelidium Schweikert \& Schnepf (1)

Ascomycota Caval.-Sm

Pezizomycotina O.E. Erikss. \& Winka

Arthoniomycetes O E Erikss. \& Wink a

Arthoniales Henssen ex D. Hawksw. \& O.E. Erikss.

Andreiomycetaceae B.P. Hodk. \& Lendemer Andreiomyces B.P. Hodk. \& Lendemer (2)

Arthoniaceae Reichenb. ex Reichenb.

Amazonomyces Bat. (2)

Arthonia Ach. (ca. $50+$ c. 300 orphaned)

Arthothelium A. Massal. $(10+$ ca. 100 orphaned $)$

Briancoppinsia Diederich, Ertz, Lawrey \& van den Boom (1)

Coniangium Fr. (4)

Coniarthonia Grube (12)

Coniocarpon DC. (6)

Crypthonia Frisch \& G. Thor (16)

\section{Recent News}

Outlineoffungi - Note 6 Outlineoffungi - Note 5 Outlineoffungi - Note 4

Figure 2 - Outline of fungi

Table 1 List of expert curators for Outline of Fungi webpage

\begin{tabular}{|c|c|c|c|}
\hline Position & Name & Field of specialty & Contact details \\
\hline Head curator & Nalin N. Wijayawardene & $\begin{array}{l}\text { Asexual fungi, } \\
\text { nomenclature }\end{array}$ & nalinwijayawardene@yahoo.com \\
\hline $\begin{array}{l}\text { Senior } \\
\text { Curator }\end{array}$ & Kevin D. Hyde & $\begin{array}{l}\text { Dothideomycetes, } \\
\text { Sordariomycetes }\end{array}$ & kdhyde3@gmail.com \\
\hline \multirow{4}{*}{$\begin{array}{l}\text { Managing } \\
\text { curators }\end{array}$} & Makbule Erdoğdu & Fungal plant pathogens & merdogdu@ahievran.edu.tr \\
\hline & Andrei Tsurykau & $\begin{array}{l}\text { Lichens, lichenicolous } \\
\text { fungi }\end{array}$ & tsurykau@gmail.com \\
\hline & Shiva Prakash Nedle & $\begin{array}{l}\text { Basidiomycota, } \\
\text { hyphomycetes }\end{array}$ & shivanedle@gmail.com \\
\hline & Josiane S. Monteiro & Asexual fungi & kiotobelbio2003@yahoo.com.br \\
\hline \multirow[t]{11}{*}{ Curators } & Alan J.L. Phillips & $\begin{array}{l}\text { Botryosphaeriales, } \\
\text { pathogens }\end{array}$ & alan.jl.phillips@gmail.com \\
\hline & André Aptroot & Lichens & andreaptroot@gmail.com \\
\hline & Bruno T. Goto & Glomeromycota & brunogoto@hotmail.com \\
\hline & Danny Haelewaters & $\begin{array}{l}\text { Leotiomycetes, } \\
\text { Laboulbeniomycetes }\end{array}$ & danny.haelewaters@gmail.com \\
\hline & Eleni Gentekaki & Basal fungi & gentekaki.ele@mfu.ac.th \\
\hline & Damien Ertz & $\begin{array}{l}\text { Lichens, lichenicolous } \\
\text { fungi }\end{array}$ & damien.ertz@jardinbotaniquemeise.be \\
\hline & Hugo Madrid & $\begin{array}{l}\text { hyphomycetes, } \\
\text { Eurotiomycetes }\end{array}$ & hugo.madrid@gmail.com \\
\hline & Marc Stadler & $\begin{array}{l}\text { Xylariales, secondary } \\
\text { metabolites of fungi }\end{array}$ & marc.stadler@helmholtz-hzi.de \\
\hline & Alfredo Vizzini & $\begin{array}{l}\text { Basidiomycota, } \\
\text { Agaricales, Boletales }\end{array}$ & alfredo.vizzini@unito.it \\
\hline & Marco Thines & $\begin{array}{l}\text { Oomycota, } \\
\text { Ustilaginomycotina, } \\
\text { nomenclature }\end{array}$ & marco.thines@senckenberg.de \\
\hline & Chuan-Gen Lin & Hyphomycetes & chuangenlin@gmail.com \\
\hline
\end{tabular}


Table 1 Continued.

\begin{tabular}{|c|c|c|c|}
\hline Position & Name & Field of specialty & Contact details \\
\hline & Yu-Cheng Dai & Basidiomycota & yuchengd@yahoo.com \\
\hline & Patrícia O. Fiuza & $\begin{array}{l}\text { Fresh water fungi, } \\
\text { asexual fungi }\end{array}$ & patyfiuzabio@gmail.com \\
\hline & Paul M. Kirk & Nomenclature & P.Kirk@kew.org \\
\hline & Don-Qin Dai & Dothideomycetes & cicidaidongqin@gmail.com \\
\hline & Ramesh K. Saxena & Fossil fungi & rksaxena2207@yahoo.com \\
\hline & $\begin{array}{l}\text { Rafael F. Castañeda- } \\
\text { Ruiz }\end{array}$ & hyphomycetes & rfcastanedaruiz@gmail.com \\
\hline & Irina S. Druzhinina & Asexual fungi & irina.s.druzhinina@mail.ru \\
\hline & Feng Cai & Asexual fungi & czfscf@hotmail.com \\
\hline & Anusha H. Ekanayaka & Leotiomycetes & hasinie88@gmail.com \\
\hline & $\begin{array}{l}\text { Sajeewa S.N. } \\
\text { Maharachchikumbura }\end{array}$ & Sordariomycetes & sajeewa83@yahoo.com \\
\hline & Sinang Hongsanan & Sooty moulds & sinang333@gmail.com \\
\hline & E.B. Gareth Jones & Aquatic fungi & torperadgj@gmail.com \\
\hline & Walter P. Pfliegler & Yeast (Ascomycota) & pfliegler.valter@science.unideb.hu \\
\hline & $\begin{array}{l}\text { Samantha C. } \\
\text { Karunarathna }\end{array}$ & Basidiomycota & samanthakarunarathna@gmail.com \\
\hline & Hyang Burm Lee & Basal fungi & hblee@jnu.ac.kr \\
\hline & Javier Etayo & $\begin{array}{l}\text { Lichens, lichenicolous } \\
\text { fungi }\end{array}$ & jetayosa@educacion.navarra.es \\
\hline & H. Thorsten Lumbsch & Lichens & tlumbsch@fieldmuseum.org \\
\hline & Rajesh Jeewon & Asexual fungi & r.jeewon@uom.ac.mu \\
\hline & R.G. Udeni Jayalal & Lichens & jayalal@appsc.sab.ac.lk \\
\hline & Qing Tian & Eurotiomycetes & tianqing124@gmail.com \\
\hline & $\begin{array}{l}\text { Dhanushka N. } \\
\text { Wanasinghe }\end{array}$ & Pleosporales & dnadeeshan@gmail.com \\
\hline & Xinlei Fan & $\begin{array}{l}\text { Diaporthales, } \\
\text { Botryosphaeriales, } \\
\text { forest pathogenic fungi }\end{array}$ & xinleifan@bjfu.edu.cn \\
\hline & Eric H.C. McKenzie & $\begin{array}{l}\text { Pucciniomycotina, } \\
\text { Ustilaginomycotina, } \\
\text { hyphomycetes }\end{array}$ & mckenziee@landcareresearch.co.nz \\
\hline & Teun Boekhout & Yeasts & t.boekhout@wi.knaw.nl \\
\hline & Vince Hustad & Geoglossales & vhustad@gmail.com \\
\hline & Dmitry Leontyev & Slime moulds & alwisiamorula@gmail.com \\
\hline & Sybren de Hoog & Clinical fungi & Sybren.deHoog@radboudumc.nl. \\
\hline & Tuula Niskanen & Agaricomycetes & t.niskanen@kew.org \\
\hline & Roger G. Shivas & Plant pathogens & roger.shivas@usq.edu.au \\
\hline & Gaya Ester & Lichens & e.gaya@kew.org \\
\hline & Wen-Jing Li & Asexual fungi & winnie20070653026@163.com \\
\hline
\end{tabular}

\section{Notes section}

The publication of notes is recognized as an important part of outlineoffungi.org, which provides details of new additions, changes or opinions. This provides an opportunity for interested parties to better understand recent changes. It will also provide a platform to express opinions and judgements on fungal taxonomy with respect to the identification and placement of fungi in different classification schemes.

Changes to the outline/ classification could be due to three main reasons:

1. Changes to classification following recent publications.

2. Additions of taxa missing in Wijayawardene et al. (2020).

3. Correction or errors in Wijayawardene et al. (2020) (e.g. duplication of names, wrong placement of taxa). 


\section{Preparing notes}

\section{Addition of new taxa from new publications}

The addition of new taxa will be coordinated with repositories such as Index Fungorum. The published materials/research articles that introduce new taxa will cross checked against repository lists by the four managing curators. Their main task will be to prepare entries for new additions. As the second step, the entries will be sent to curator/s for checking. Once the managing curator has edited the entry according to curators' comments, the senior curator and the head curator will check the entries. The head curator will cross check the validity of the taxa against repositories (e.g. Index Fungorum) and upload the entry.

A list of new taxa (genus level and above) will be gathered from Index Fungorum twice a year and cross checked against the entries provided in outlineoffungi.org. This will help to maintain a current outline.

Authors who publish new taxa are also encouraged to provide entries. This includes resurrection of synonymized genera in recent publications (e.g. Thiyagaraja et al. 2020).

\section{Addition of missing taxa}

Notes for missing taxa will be mainly expected from expert mycologists. They can prepare the entries and send these to the head curator. The curator/s will check and correct the entries which will be uploaded to the webpage.

\section{Correcting mistakes in the existing outline}

Notes which correct mistakes (such as duplication of names, incorrect author citations) will also be acceptable. However, the senior curator and the head curator will decide whether it is necessary to upload the note, or correct the web version of the outline.

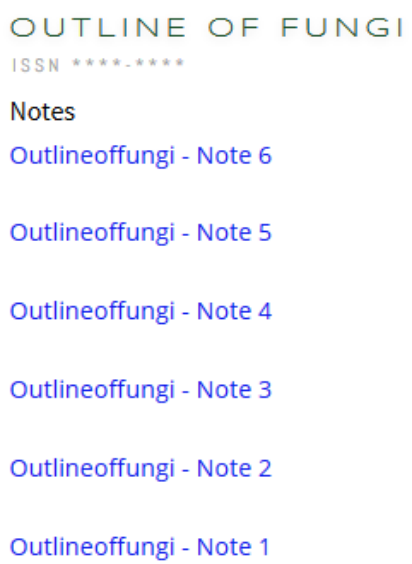

Figure 3 - Notes section

\section{A platform to exchange different opinions}

Different opinions on higher classification and synonymy of pleomorphic genera (Art. 59.1) are two important topics that can lead to confusion. For example, the higher-level classification of Leotiomycetes in Ekanayaka et al. (2019) is different from the classification in Johnston et al. (2019). Two main differences account for the alternative classification schemes: (i) the amount of sequence data [5-locus by Ekanayaka et al. (2019) vs 15-locus and genomic-scale by Johnston et al. (2019)] and (ii) the inclusion of type species and ex-type sequences in Johnston et al's (2019) analyses. However, the presentation of the alternative classifications provide perspective for 
general users and mycologists interested in Leotiomycetes taxonomy. Further, if other authors have different opinions on existing classifications, we encourage them to provide them in the notes section.

Adopted or proposed names for pleomorphic genera are also controversial in some cases. For example, Wijayawardene et al. (2014) proposed to adopt Anthracostroma Petr. 1954 over Camarosporula Petr. 1954, but Rossman et al. (2015) did not agree and proposed to adopt the latter name over the former. This type of disagreement and controversial opinions might cause confusion among users if future authors referred to only one publication. Thus, it is essential to have a platform such as http://outlineoffungi.org to provide different opinions, which can eventually culminate in a consensus towards species concepts.

\section{Links between sexual and asexual morphs}

The new webpage also provides links between sexual and asexual morphs with the names that have been adopted for pleomorphic genera since 2011 (Art. 59.1). Wijayawardene et al. (2017b) provided the adopted names of pleomorphic genera based on previous studies (e.g. Wijayawardene et al. 2014, Rossman et al. 2015), but it is intended to include all pleomorphic genera according to recent developments and recommendations from the International Commission on the Taxonomy of Fungi.

\section{A place to obtain data (from genus to higher rank) for phylogenetic analyses}

Selecting taxa for phylogenetic studies is a challenge as it is important to include closely related genera in the analyses. Extracting data from static publications might cause problems due to outdated views on phylogenetic relationships. Thus, it is important to obtain data from a database that is kept updated. Since outlineoffungi.org will be continuously updated, with the supervision of senior taxonomists, users can obtain a list of related genera from it for their phylogenetic analyses and morphological comparisons.

\section{Acknowledgements}

This work was supported by the Key Laboratory of Yunnan Province Universities of the Diversity and Ecological Adaptive Evolution for Animals and Plants on the Yun-Gui Plateau, the National Natural Science Foundation of China (No. NSFC 31950410558, NSFC 31760013, 31260087, 31460561), and the Scientific Research Foundation of Yunnan Provincial Department of Education (2017ZZX186). Nalin N. Wijayawardene gratefully acknowledges grant number FAMP201906K provided by Guizhou Medical University. Kevin D. Hyde thanks the Foreign Experts Bureau of Yunnan Province, Foreign Talents Program (2018; grant no. YNZ2018002), Thailand Research grants entitled Biodiversity, phylogeny and role of fungal endophytes on above parts of Rhizophora apiculata and Nypa fruticans (grant no: RSA5980068), the future of specialist fungi in a changing climate: baseline data for generalist and specialist fungi associated with ants, Rhododendron species and Dracaena species (grant no: DBG6080013), Impact of climate change on fungal diversity and biogeography in the Greater Mekong Subregion (grant no: RDG6130001). Dong-Qin Dai would like to thank the Thousand Talents Plan, Youth Project of Yunnan Provinces for support. Alan JL Phillips acknowledges the support from UIDB/04046/2020 and UIDP/04046/2020 Centre grants from FCT, Portugal (to BioISI).

\section{References}

Adl SM, Simpson AG, Farmer MA, Andersen RA et al. 2005 - The new higher level classification of eukaryotes with emphasis on the taxonomy of protists. Journal of Eukaryotic Microbiology 52, 399-451. Doi: 10.1111/j.1550-7408.2005.00053.x

Ainsworth GC. 1966 - A general purpose classification of fungi. Bibliography of Systematic Mycology 1, 1-4. 
Beakes GW, Thines M. 2017 - Hyphochytriomycota and Oomycota. In: Archibald J, Simpson A, Slamovits C (eds) Handbook of the Protists. Springer International Publishing, Cham, pp. 435-505.

Buaya AT, Ploch S, Hanic L, Nam B et al. 2017 - Phylogeny of Miracula helgolandica gen. et sp. nov. and Olpidiopsis drebesii sp. nov., two basal oomycete parasitoids of marine diatoms, with notes on the taxonomy of Ectrogella-like species. Mycological Progress 16, 1041-1050. Doi: 10.1007/s11557-017-1345-6

Burki F, Shalchian-Tabrizi K, Minge M, Skjæveland Å et al. 2007 - Phylogenomics reshuffles the eukaryotic supergroups. PloS ONE 2, e790. Doi: 10.1371/journal.pone.0000790

Dick MW. 2001 - Straminipilous Fungi. Springer, Dordrecht.

Dilcher DL. 1965 - Epiphyllous fungi from Eocene deposits in western Tennessee, U.S.A. Palaeontographica Abt. B 116, 1-54.

Ekanayaka AH, Hyde KD, Gentekaki E, McKenzie EHC et al. 2019 - Preliminary classification of Leotiomycetes. Mycosphere 10, 310-489. Doi: 10.5943/mycosphere/10/1/7

Eriksson OE. 1982 - Outline of the Ascomycetes - 1982. Mycotaxon 15, 203-248.

Eriksson OE. 1999 - Outline of Ascomycota - 1999. Myconet 3, 1-88.

Eriksson OE. 2001 - SSU rDNA sequences from Ascomycota. Myconet 6, 27-76.

Eriksson OE. 2005 - Outline of Ascomycota - 2005. Myconet 11, 1-113.

Eriksson OE, Hawksworth DL. 1986 - Outline of the ascomycetes-1986. Systema Ascomycetum 5, 185-324.

Eriksson OE, Hawksworth DL. 1998a - Outline of the ascomycetes - 1998. - Systema Ascomycetum 16, 83-296.

Eriksson OE, Hawksworth DL. 1998b - Notes on ascomycete systematics. Nos 2256-2439. Systema Ascomycetum 16, 39-81.

Hawksworth DL, Crous PW, Redhead SA, Reynolds DR et al. 2011 - The Amsterdam declaration on fungal nomenclature. IMA Fungus 2: 105-112.

He MQ, Zhao RL, Hyde KD, Begerow D et al. 2019 - Notes, outline and divergence times of Basidiomycota. Fungal Diversity 99, 105-367. Doi: 10.1007/s13225-019-00435-4.

Hyde KD, McKenzie EHC, KoKo TW. 2011 - Towards incorporating anamorphic fungi in a natural classification -checklist and notes for 2010. Mycosphere 2, 1-88.

Jiang S, Lücking R, Xavier-Leite AB, Marcela ES et al. 2020 - Reallocation of foliicolous species of the genus Strigula into six genera (lichenized Ascomycota, Dothideomycetes, Strigulaceae). Fungal Diversity. Doi: 10.1007/s13225-020-00445-7.

Jayawardena RS, McKenzie EHC, Chen YJ, Phillips AJL et al. 2019 https://onestopshopfungi.org/, a database to enhance identification of phytopathogenic genera. Asian Journal of Mycology 2, 281-286. Doi: 10.5943/ajom/2/1/18

Jayasiri SC, Hyde KD, Ariyawansa HA, Bhat DJ et al. 2015 - The Faces of Fungi database: fungal names linked with morphology, phylogeny and human impacts. Fungal Diversity 74, 3-18. Doi: 10.1007/s13225-015-0351-8

Jones EBG, Pang KL, Abdel-Wahab MA, Scholz B, et al. 2019 - An online resource for marine fungi. Fungal Diversity 96, 347-433.

Johnston PR, Quijada L, Smith CA, Baral HO et al. 2019 - A multigene phylogeny toward a new phylogenetic classification for the Leotiomycetes. IMA Fungus 10, 1. Doi: 10.1186/s43008019-0002-x

Kalgutkar RM, Jansonius J. 2000 - Synopsis of fungal spores, mycelia and fructifications. AASP Contribution Series 39, 1-423.

Kendrick WB. 1989 - Subdivision Deuteromycotina a fungal chimera. Sydowia 41, 6-14.

Leontyev DV, Schnittler M, Stephenson S, NovozhilovYK et al. 2019 - Towards a phylogenetic classification of Myxomycetes. Phytotaxa 399, 209-238.

Lumbsch HT, Huhndorf SM. 2007 - Outline of Ascomycota-2017. Myconet 13, 1-99. 
Lumbsch HT, Huhndorf SM. 2010 - Myconet Volume 14. Part one. Outline of Ascomycota 2009. Part Two. Notes on Ascomycete Systematics. Nos. 4751-5113. Fieldiana Life Earth Sci 1, 164. Doi: $10.3158 / 1557.1$

Monkai J, McKenzie EHC, Phillips AJL, Hongsanan S et al. 2019 - https://fungalgenera.org/: a comprehensive database providing webbased information for all fungal genera. Asian Journal of Mycology 2, 298-305. Doi: 10.5943/ajom/2/1/20

Pem D, Hongsanan S, Doilom M, Tibpromma S et al. 2019 - https://www.dothideomycetes.org: An online taxonomic resource for the classification, identification, and nomenclature of Dothideomycetes. Asian Journal of Mycology 2, 287-297. Doi: 10.5943/ajom/2/1/19

Pirozynski KA, Weresub LK. 1979 - The classification and nomenclature of fossil fungi. in Kendrick, B. (ed.), The whole fungus, the sexual-asexual synthesis. Proceedings of the $2^{\text {nd }}$ International Mycological Conference, University of Calgary, Kananaskis, Alberta (published by National Museum of Natural Sciences, National Museums of Canada and the Kananaskis Foundation) volume 2, 653-688.

Prakash PY, Irinyi L, Halliday C, Chen S et al. 2017 - Online Databases for Taxonomy and Identification of Pathogenic Fungi and Proposal for a Cloud-Based Dynamic Data Network Platform. Journal of Clinical Microbiology 55, 1011-1024. Doi: 10.1128/JCM.02084-16

Quijada L, Tanney JB, Popov E, Johnston PR et al. 2020 - Cones, needles and wood: Micraspis (Micraspidaceae, Micraspidales fam. et ord. nov.) speciation segregates by host plant tissues. Fungal Systematics and Evolution 5, 99-112. Doi: 10.3114/fuse.2020.05.05

Ronikier A, Halamski AT. 2018 - Is Myxomycetes (Amoebozoa) a truly ambiregnal group? A major issue in protist nomenclature. Protist 169, 484-493.

Rossman AY, Crous PW, Hyde KD, Hawksworth DL et al. 2015 - Recommended names for pleomorphic genera in Dothideomycetes. IMA fungus 6, 507-523.

Doi: 10.5598/imafungus.2015.06.02.14

Saccardo PA. 1904 - De Diagnostica et nomenclatura mycologica, Admonita quaedam. Annales Mycologici 2, 195-198. [English translation by Clements FE (1904) J Mycol 10, 109-112]

Samarakoon MC, Thongbai B, Hyde KD, Brnstrup M et al. 2020 - Elucidation of the life cycle of the endophytic genus Muscodor and its transfer to Induratia in Induratiaceae fam. nov., based on a polyphasic taxonomic approach. Fungal Diversity 101, 177-210. Doi: 10.1007/s13225020-00443-9

Saxena RK, Tripathi SKM. 2011 - Indian Fossil Fungi. Palaeobotanist 60, 1-208.

Sutton BC. 1980 - The Coelomycetes. Fungi imperfecti with pycnidia, acervuli and stromata. Commonwealth Mycological Institute, Kew.

Taylor JW. 1995 - Making the Deuteromycota redundant: a practical integration of mitosporic and meiosporic fungi. Canadian Journal of Botany 73 (Suppl.), s754-s759.

Thines M, Choi YJ. 2016 - Evolution, diversity, and taxonomy of the Peronosporaceae, with focus on the genus Peronospora. Phytopathology 106, 6-18. Doi: 10.1094/PHYTO-05-15-0127RVW

Thiyagaraja V, Lücking R, Ertz D, Wanasinghe DN et al. 2020 - Evolution of non-lichenized, saprotrophic species of Arthonia (Ascomycota, Arthoniales) and resurrection of Naevia, with notes on Mycoporum. Fungal Diversity. Doi: 10.1007/s13225-020-00451-9

Větrovský T, Morais D, Kohout P, Lepinay C et al. 2020 - Global Fungi, a global database of fungal occurrences from high-throughput-sequencing metabarcoding studies. Scientific Data 7, 228. Doi: 10.1038/s41597-020-0567-7

White TJ, Bruns T, Lee S, Taylor JW. 1990 - Amplification and direct sequencing of fungal ribosomal RNA genes for phylogenetics. In: Innis MA, Gelfand DH, Sninsky JJ \& White TJ (eds) PCR protocols: a guide to methods and applications, New York Academic Press, pp 315-322.

Wibberg D, Stadler M, Lambert C, Bunk B et al. 2020 - High quality genome sequences of thirteen Hypoxylaceae (Ascomycota) strengthen the phylogenetic family backbone and enable the discovery of new taxa. Fungal Diversity. Doi: 10.1007/s13225-020-00447-5 
Wijayawardene NN, Crous PW, Kirk PM, Hawksworth DL et al. 2014 - Naming and outline of Dothideomycetes-2014 including proposals for the protection or suppression of generic names. Fungal Diversity 69: 1-55. Doi: 10.1007/s13225-014-0309-2

Wijayawardene NN, Hyde KD, Rajeshkumar KC, Hawksworth DL et al. 2017a - Notes for genera: Ascomycota. Fungal Diversity 86, 1-594. Doi: 10.1007/s13225-017-0386-0

Wijayawardene NN, Hyde KD, Tibpromma S, Wanasinghe DN et al. 2017b - Towards incorporating asexual fungi in a natural classification: checklist and notes 2012-2016. Mycosphere 8:1457-1554. Doi: 10.5943/mycosphere/8/9/10

Wijayawardene NN, Hyde KD, Lumbsch HT, Liu JK et al. 2018 - Outline of Ascomycota: 2017. Fungal Diversity 88, 167-263. Doi: 10.1007/s13225-018-0394-8

Wijayawardene NN, Hyde KD, Al-Ani LK, Tedersoo L et al. 2020 - Outline of Fungi and funguslike taxa. Mycosphere 11, 1060-1456. Doi: 10.5943/mycosphere/11/1/8 